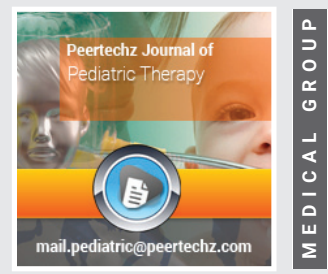

\title{
An analysis of microorganisms isolated from wound cultures in pediatric cases
}

\author{
Muhammed Yusuf Ozan Avcı ${ }^{1 *}$ and Metin Doğan ${ }^{2}$ \\ 'Department of Pediatrics, Necmettin Erbakan University, Meram Faculty of Medicine, Konya, Turkey \\ ${ }^{2}$ Department of Medical Microbiology, Necmettin Erbakan University, Meram Faculty of Medicine, \\ Konya, Turkey
}

Received: 27 April, 2020

Accepted: 16 June, 2020

Published: 17 June, 2020

*Corresponding author: Muhammed Yusuf Ozan Avcl, Department of Pediatrics, Necmettin Erbakan University, Meram Faculty of Medicine, Konya, Turkey,

E-mail:m.yusufozan@gmail.com

Keywords: Wound culture; Pediatrics; Reproductive microorganisms

https://www.peertechz.com

- - - - - - - - - - - - - - - ,

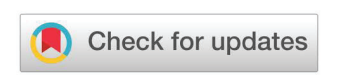

\section{Abstract}

Introduction: Nowadays, thanks to the advancements in the follow-ups and treatments of diseases, more patients have been hospitalized. Especially chronic diseases such as cancers, increases infection risk. Although there is not much data in the literature about wound cultures in pediatric cases, it was found that wound infection has most commonly seen in the departments of general surgery and pediatric clinics respectively, as expected. Therefore, it is essential to know the microorganisms isolated from wounds in pediatric cases in terms of empirical treatment.

In this study, we aim to evaluate microorganisms isolated from wound cultures in pediatric cases retrospectively.

Materials and methods: Specimens accepted to the Medical Microbiology laboratory from the samples taken from the wound infections in the pediatric clinic of Necmettin Erbakan University Meram Faculty of Medicine Hospital between 01.01.2016 and 31.12.2018 were included in the study. Routinely, blood agar and Eosin methylene blue (EMB) agar were cultured at $37^{\circ} \mathrm{C}$ for 24 hours in an aerobic environment. Anaerobic cultures were not routinely done. Microorganisms growth and thought to be active in cultures have been identified by conventional methods and MALDI-TOF MS system/VITEC MS system (Bio Merieux, France).

Results: Of the 45 microorganisms isolated from wound cultures, the most frequent one wasPseudomonas aeruginosa with $35.5 \%$ of them ( $\mathrm{n}=16$ ). Speaking of other species, $20 \%$ were Acinetobacter baumannii $(n=9), 13.3 \%$ were Candida spp. $(n=6), 11 \%$ were Klebsiella pneumoniae( $n=5), 8.8 \%$ were Escherichia coli $(n=4), 8.8 \%$ were Staphylococcus aureus $(\mathrm{n}=4)$ and $2.2 \%$ were Achromobacter denitrificans $(\mathrm{n}=1)$.

Conclusion: Consequently, it was concluded that $P$. aeruginosa and $A$. baumanniiwere the most common germs growth in wound cultures. Hence this fact should be taken into consideration while starting empiric antibiotherapy to children with wound infection.

It is common information that isolated microorganisms may differentiate according to studying center and laboratories

\section{Introduction}

Nowadays, more patients have been hospitalized with thanks to the advancements in the follow-ups and treatments of diseases. Infections are more frequently observed in hospitals with the increase of inpatients. Especially chronic diseases such as cancers, increases infection risk. In addition to long term hospitalizations for the treatment of diseases present in many patients with chronic diseases, they also increase the risk of infection development; especially in patients with immune deficiency and/or poor general status. These infections significantly affect morbidity and mortality, too. Bacteria are often blamed as infectious agents. Therefore, it has a great importance to know the frequency of infectious agents in patient groups in terms of follow-up and treatment [1-3].

Wound infections are important in follow-ups. Wound infections occur as a result of microorganisms settling and spreading by defeating the immune response [1-3]. These infections vary greatly in terms of both the clinical picture and responsible microorganisms [4]. Wound infections are one of the most common comorbid problems, especially in cases with surgery. But they are generally an important health issue in developing countries [5,6]. 
Although there is not much data in the literature about wound cultures in pediatric cases, it was found that wound infection has most commonly seen in the departments of general surgery and pediatric clinics respectively, as expected [7]. Therefore, it is essential to know the microorganisms isolated from wounds in pediatric cases in terms of empirical treatment.

In this study, we aim to evaluate microorganisms isolated from wound cultures in pediatric cases retrospectively.

\section{Materials and methods}

Specimens accepted to the Medical Microbiology laboratory from the samples taken from the wound infections in the pediatric department of Necmettin Erbakan University Meram Faculty of Medicine Hospital between 01.01.2016 and 31.12.2018 were included in the study. Routinely, blood agar and Eosin methylene blue (EMB) agar were cultured at $37^{\circ} \mathrm{C}$ for 24 hours in an aerobic environment. Anaerobic cultures were not routinely done. Microorganisms growth and thought to be active in cultures have been identified by conventional methods and MALDI-TOF MS system/VITEC MS system (Bio Merieux, France).

\section{Results}

A total of 45 patients were included in the study. Demographic data of the patients who are included study are given in the Table 1. Bacteria were isolated in Intensive Care Unit patients, mostly. Distributions of samples isolated the bacteria according to department are given in the Table 2 . Bacteria were most frequently isolated in tracheostomy area open wound. The rates of bacteria isolated by location are given in Table 3.

Of the 45 microorganisms isolated from wound cultures, the most frequent one was Pseudomonas aeruginosa with
$35.5 \%$ of them $(n=16)$. Speaking of other species, $20 \%$ were Acinetobacter baumannii $(\mathrm{n}=9), 13.3 \%$ were Candida spp. $(\mathrm{n}=6)$, $11 \%$ were Klebsiella pneumoniae $(\mathrm{n}=5), 8.8 \%$ were Escherichia coli $(\mathrm{n}=4), 8.8 \%$ were Staphylococcus aureus $(\mathrm{n}=4)$ and $2.2 \%$ were Achromobacter denitrificans $(\mathrm{n}=1)$.The microorganisms isolated according to years shows in Table 4 .

\section{Discussion}

Defining the factors of nosocomial infections and starting appropriate empiric ant biotherapy is a crucial step of the treatment. The most important step is cultivation and antibiogram. Wound culture is also one of them. However, it may not always be possible to identify the responsible agent of infection, and also sometimes treatment may be urgent and required without waiting for the culture result. Thus, it is important to know the regional infectious agents.

There are several studies investigating the site of wound infection in children. In a study, Escherichia coli (28.5\%) was the first among the isolated microorganisms; followed by Enterobacter aerogenes (15.6\%), S. aureus (14.8\%) and P. aeruginosa (14\%) [7]. In a study performed in the pediatric burn unit of Şişli Etfal Training and Research Hospital, P. aeruginosa (\%38.1) was the most common one, then Candida spp. (\%19.0) and $S$. aureus were isolated. This was followed by Klebsiella pneumoniae and other microorganisms [8]. In another study, Pseudomonas aeruginosa was most commonly isolated as wound site infections. Other factors followed this [9]. In our study, $P$. aeruginosa and A. baumannii were isolated in more than $50 \%$ of wound cultures, and Candida spp. isolated.

As a result, it was concluded that $P$. aeruginosa and $A$. baumannii were most common in wound infections and proper ant biotherapy should be taken into consideration.

However, wound areas are generally interventional operations. So operations must be avoided when possible.

Table 1: Demographic data of the patients who are included study

\begin{tabular}{|c|c|c|c|c|c|c|c|c|}
\hline & \multicolumn{2}{|c|}{ Gender } & \multirow{2}{*}{ Total } & \multicolumn{4}{|c|}{ Age } & \multirow{2}{*}{ Total } \\
\hline & Male & Female & & $<6$ & $6-10$ & $10-15$ & $15<$ & \\
\hline 2016 n-\% & $8-53,33 \%$ & $7-46,66 \%$ & 15 & $9-60 \%$ & - & $6-40 \%$ & - & 15 \\
\hline 2017 n-\% & $5-38,46 \%$ & $8-61,53 \%$ & 13 & $6-46,15 \%$ & - & $3-23,07 \%$ & $4-30,76 \%$ & 13 \\
\hline 2018 n-\% & $9-52,94 \%$ & $8-47,05 \%$ & 17 & $7-41,17 \%$ & $2-11,76 \%$ & $3-17,64 \%$ & $5-29,41 \%$ & 17 \\
\hline TOTAL & $22-48,88 \%$ & $23-51,11 \%$ & 45 & $22-48,88 \%$ & $2-4,44 \%$ & $12-26,66 \%$ & $9-20 \%$ & 45 \\
\hline
\end{tabular}

Table 2: Distributions of samples isolated the bacteria according to department.

\begin{tabular}{|c|c|c|c|c|c|}
\hline & & $\begin{array}{c}2016 \\
n-\%\end{array}$ & $\begin{array}{c}2017 \\
n-\%\end{array}$ & $\begin{array}{c}2018 \\
n-\%\end{array}$ & $\begin{array}{c}\text { TOTAL } \\
\text { n-\% }\end{array}$ \\
\hline \multirow{8}{*}{ Department } & Intensıve Care Unıte & $6-40 \%$ & $4-30,76 \%$ & $10-58,82 \%$ & $20-44,44 \%$ \\
\hline & Pediatrics Neurology & - & - & $1-5,88 \%$ & $1-2,22 \%$ \\
\hline & Pediatrics İnfectious Disease & $6-40 \%$ & $2-15,38 \%$ & $1-5,88 \%$ & $9-20 \%$ \\
\hline & Pediatric Endocrinology & - & $1-7,69 \%$ & - & $1-2,22 \%$ \\
\hline & Pediatric Hematology And Oncology & $2-13,33 \%$ & $6-46,15 \%$ & - & $8-17,77 \%$ \\
\hline & Pediatric Nefrology & - & - & $2-11,76 \%$ & $2-4,44 \%$ \\
\hline & Neonatology Unit & $1-6,66 \%$ & - & $2-11,76 \%$ & $3-6,66 \%$ \\
\hline & Pediatric Chest Disease & - & - & $1-5,88 \%$ & $1-2,22 \%$ \\
\hline \multicolumn{2}{|r|}{ Total } & 15 & 13 & 17 & 45 \\
\hline
\end{tabular}


Table 3: The rates of bacteria isolated by location.

\begin{tabular}{|c|c|c|c|c|c|}
\hline \multirow{10}{*}{$\begin{array}{l}\text { Wound } \\
\text { Area }\end{array}$} & $\begin{array}{l}\text { Tracheostomy Area } \\
\text { Open Wound }\end{array}$ & $6-40 \%$ & $1-7,69 \%$ & $5-29,41 \%$ & $12-26,66 \%$ \\
\hline & $\begin{array}{l}\text { Postoperatıve } \\
\text { Open Wound }\end{array}$ & $2-13,33 \%$ & - & $1-5,88 \%$ & $3-6,66 \%$ \\
\hline & $\begin{array}{l}\text { Gastrostomy Area } \\
\text { Open Wound }\end{array}$ & $3-20 \%$ & $3-23,07 \%$ & $3-17,64 \%$ & $9-20 \%$ \\
\hline & $\begin{array}{c}\text { Spontan } \\
\text { Open Wound }\end{array}$ & $1-6,66 \%$ & - & & $1-2,22 \%$ \\
\hline & $\begin{array}{l}\text { Decubitus } \\
\text { Ulcer }\end{array}$ & - & $4-30,76 \%$ & & $4-8,88 \%$ \\
\hline & $\begin{array}{l}\text { Developıng After } \\
\text { Traffıc Accıdent } \\
\text { Open Wound }\end{array}$ & - & - & $3-17,64 \%$ & $3-6,66 \%$ \\
\hline & $\begin{array}{l}\text { Wound To The } \\
\text { Catheter }\end{array}$ & - & $1-7,69 \%$ & $3-17,64 \%$ & $4-8,88 \%$ \\
\hline & Abscess & - & $1-7,69 \%$ & $2-11,76 \%$ & $3-6,66$ \\
\hline & $\begin{array}{c}\text { From Ectima } \\
\text { Gangrenosum Lesion }\end{array}$ & - & $2-15,38 \%$ & - & $2-4,44 \%$ \\
\hline & Unknown & $3-20 \%$ & $1-7,69 \%$ & & $4-4,44 \%$ \\
\hline & Total & 15 & 13 & 17 & 45 \\
\hline
\end{tabular}

Table 4: The microorganisms isolated according to years.

\begin{tabular}{|c|c|c|c|c|}
\hline Isolated microorganisms & $\begin{array}{c}\mathbf{2 0 1 6} \text { year } \\
\mathbf{n}-\%\end{array}$ & $\begin{array}{c}\mathbf{2 0 1 7} \text { year } \\
\mathbf{n}-\%\end{array}$ & $\begin{array}{c}\mathbf{2 0 1 8} \text { year } \\
\mathbf{n}-\%\end{array}$ & $\begin{array}{c}\text { Total } \\
\mathbf{n}-\%\end{array}$ \\
\hline P. aeruginosa & $6-40 \%$ & $3-23.07 \%$ & $7-41.17 \%$ & $16-35.5 \%$ \\
\hline A. baumannii & $4-26.66 \%$ & - & $5-29.41 \%$ & $9-20 \%$ \\
\hline Candida spp. & $2-13.33 \%$ & $2-15.38 \%$ & $2-11.76 \%$ & $6-13.3 \%$ \\
\hline K. pneumoniae & $1-6.66 \%$ & $3-23.07 \%$ & $1-5.88 \%$ & $5-11 \%$ \\
\hline E. coli & $1-6.66 \%$ & $3-23.07 \%$ & - & $4-8.8 \%$ \\
\hline S. aureus & - & $2-15.38 \%$ & $2-11.76 \%$ & $4-8.8 \%$ \\
\hline A.denitrificans & $1-6.66 \%$ & - & - & $1-2.2 \%$ \\
\hline Total & 15 & 13 & 17 & 45 \\
\hline
\end{tabular}

Especially, patients should be careful when entering the hospital environment after operations.

\section{References}

1. Barbul A (2005) Wound healing. In: Brunicardi FC ed. Schwartz's Principles of Surgery. 8th ed. New York: McGraw-Hill 223-249.

2. Peel ALG (1992) Definition of infection. In: Taylor EW ed. Infection in Surgical Practice. Oxford: Oxford University Press 82-87.

3. Uzunköy A (2005) Cerrahi alan infeksiyonları. Risk faktörleri ve önleme yöntemleri. Ulus Travma Dergi 11: 269-281. Link: https://bit.ly/30SEBzQ

4. Bilgehan H (2009) Klinik Mikrobiyolojik Tanı. 5.baskı. İzmir: Barış Yayınları.

5. Özkan S, Özkan FC (2002) İlçe hastanesinde genel cerrahi spektrumu. Ulusa Cerrahi Dergisi 18: 122-126.

6. Koneman EW, Stephan DA, Janda WM, Schreckenberger PC, Winn WC (1992) Diagnostic Microbiology. 4th Ed. Philadelphia: Lippincott Co.

7. Doğan S, Paköz M (2010) Aral Laboratuvarımıza gönderilen yara yeri örneklerinden izole edilen mikroorganizmalar ve antibiyotiklere direnç durumları. Türk Mikrobiyol Cem Derg 40: 243-249. Link: https://bit.ly/3e9w0fT

8. Diler B, Dalgıç N, Karadağ ÇA, Dokucu Ai (2012) Bir pediatrik yanık ünitesinde epidemiyoloji ve enfeksiyonlar: Üç yıllık deneyimimiz. Bir Pediatrik Yanık Ünitesinde Epidemiyoloji ve Enfeksiyonlar: Üç Yıllık Deneyimimiz. J Pediatr Inf 6: 40-45. Link: https://bit.ly/2URAWPc

9. Akçay A, Türel Ö, Tuğcu D, Aydoğan G, Kazancı S, et al. (2011) Çocuk hematoloji-onkoloji hastalarına ait klinik örneklerden izole edilen bakterilerin ve antibiyotik duyarlılıklarının incelenmesi. JOPP Derg 3: 68-73. Link: https://bit.ly/37EtcVy

\section{Discover a bigger Impact and Visibility of your article publication with} Peertechz Publications

\author{
Highlights \\ * Signatory publisher of ORCID \\ * Signatory Publisher of DORA (San Francisco Declaration on Research Assessment) \\ * Articles archived in worlds' renowned service providers such as Portico, CNKI, AGRIS, \\ TDNet, Base (Bielefeld University Library), CrossRef, Scilit, J-Gate etc. \\ * Journals indexed in ICMJE, SHERPA/ROMEO, Google Scholar etc. \\ * OAI-PMH (Open Archives Initiative Protocol for Metadata Harvesting) \\ * Dedicated Editorial Board for every journal \\ * Accurate and rapid peer-review process \\ * Increased citations of published articles through promotions \\ * Reduced timeline for article publication \\ Submit your articles and experience a new surge in publication services \\ (https://www.peertechz.com/submission).
}

Peertechz journals wishes everlasting success in your every endeavours.

Copyright: @ 2020 Ozan Avcı MY, et al. This is an open-access article distributed under the terms of the Creative Commons Attribution License, which permits unrestricted use, distribution, and reproduction in any medium, provided the original author and source are credited. 